UDC 635.52:631.52

KECKALO V., Candidate of Agricultural Sciences, Associate Professor

Uman National University of Horticulture

e-mail: viktoriya_keckalo@ukr.net

\title{
PRODUCTIVITY HEAD LETTUCE IN SPRING GREEN HOUSES
}

In this scientific article we present the results of researches based on head lettuce sorts of Alanis and Stallion efficiency growing by seedlings planting in the closed soil. There was determined the influence of planting method and plants nourishing during the planting period on their growth, development and biometrical indexes. There was also determined the productivity level and marketability of the production.

Key words: head lettuce, seedlings, cassette, Alanis sort, Stallion sort, productivity.

Introduction. There is an unchanging and swift tendency to the increase of consumption and accordingly growing of head lettuce in Ukraine which important element is the usage of seedling planting cassettes method. The leading country in lettuce growing is China $(1,3$ million/t). In Europe - Spain where it is the most important vegetable right after tomatoes, onions and pepper. In Netherlands the annual production of lettuce is 100 thousand of tons, in Italy - 750-800 thousand/t., in France - 430 thousand/t., in Germany - 320 thousand/t. Specific gravity of the production in these countries is 7,9-9,0\% from the general production of vegetables [1]. In Germany lettuce takes area of 14 thousand of hectares, in Cuba - 2 thousands of hectares, in Russia about 800 hectares [2]. In general Western European countries grow around 2,5-3 million tons of lettuce annually with an import of about $30 \%$ [3]. In Ukraine the annual production of lettuce is about 14 thousand of tons which is $0,2 \%$ of general vegetable production [4]. 
Materials and methods. Researches were made during 2011-2012 in a spring greenhouses of Uman NUH with the head lettuce Alanis sort (oily leaves type) and Stallion (crisp leaves type). Researches were made according to the generally accepted methods $[5,6,7,8]$. According to the research scheme seedlings were planted by non-cassette method in polyvinychloride cassettes with the size of $2,5 \times 2,5,4 \times 4$ and $6 \times 6 \mathrm{~cm}$. Seeds were sowed in the first decade of February. After those 35 days old seedlings were planted into the soil to thicken cucumbers in the first decade of March according to the scheme of $30 \times 30 \mathrm{~cm}$, that responds to the plant thickness of 11 plants by $1 \mathrm{~m}^{2}$.

During the research there were made phonological observations, biometrical measuring's of plants and harvest account according to the generally accepted methods and recommendations. During planting period there were noticed single and mass seedlings appearance and development of the first actual leaf. After landing into the hothouse soil there were marked the beginning of head forming and technical ripeness. During a vegetation period there was measured the diameter of leaves bunch, their amount - by the counting method; the area of leaves was determined by a calculating method using the coefficient of 0,74. During harvesting the yield was assorted on standart and non-standart heads in obedience to state standard specifications 2175-93 "Green vegetables". There was measured the diameter of commodity heads of lettuce and their weight.

Results and discussion. The estimation of head lettuce seedlings quality according to the biometrical indexes testifies that number of leaves on plants at the moment of landing it into hothouse soil was almost at the same level in all experiment variants. As to the amount of leaves the best mark was with the Alanis sort, and plants which got more leaves were those planted according to the noncassette method of growing (control) and with the usage of cassettes of $6 \times 6 \mathrm{~cm}$.

As for the diameter of leaves rosette the highest were those with the usage of cassette size of $4 \times 4 \mathrm{~cm}$ and $6 \times 6 \mathrm{~cm}$. The lowest index was with the variant of growing with the cassette size of $2,5 \times 2,5 \mathrm{~cm}$ (table 1 ). 


\section{Biometrical indexes of head lettuce seedlings planting according to}

the sort and method of growing (average for 2011-2012)

\begin{tabular}{|c|c|c|c|c|c|}
\hline $\begin{array}{c}\text { Method of growing and } \\
\text { cassette size }\end{array}$ & $\begin{array}{c}\text { Number of } \\
\text { leaves, } \\
\text { unit }\end{array}$ & $\begin{array}{c}\text { Diameter of } \\
\text { a leaf } \\
\text { rosette, } \mathrm{cm}^{2}\end{array}$ & $\begin{array}{c}\text { Leaf area } \\
\mathrm{cm}^{2}\end{array}$ & $\begin{array}{c}\text { Leaf area, } \\
\mathrm{cm}^{2} / \text { plant }\end{array}$ \\
\hline \multicolumn{5}{|c|}{ Alanis sort } \\
\hline Non-cassette - control & 5,3 & 18,8 & 24,2 & 128,0 \\
\hline \multirow{4}{*}{ Cassette } & $2,5 \times 2,5 \mathrm{~cm}$ & 5,0 & 17,6 & 23,5 & 118,0 \\
\cline { 2 - 6 } & $4 \times 4 \mathrm{~cm}$ & 5,2 & 19,3 & 25,0 & 130,0 \\
\cline { 2 - 6 } & $6 \times 6 \mathrm{~cm}$ & 5,3 & 21,4 & 36,4 & 193,0 \\
\hline \multicolumn{5}{|c|}{ Stallion sort } \\
\hline \multirow{4}{*}{ Non-cassette - control } & 4,6 & 18,5 & 28,0 & 129,0 \\
\hline \multirow{2}{*}{ Cassette } & $2,5 \times 2,5 \mathrm{~cm}$ & 4,4 & 16,9 & 21,4 & 94,0 \\
\cline { 2 - 6 } & $4 \times 4 \mathrm{~cm}$ & 4,6 & 18,4 & 27,8 & 128,0 \\
\cline { 2 - 6 } & $6 \times 6 \mathrm{~cm}$ & 4,9 & 20,3 & 34,6 & 170,0 \\
\hline
\end{tabular}

The important index of photosynthetic productivity is an average area of one leaf and leaves area of a plant. The greatest index of one leaf area in researched plants was noticed when growing using the cassette method with the size of $6 \times 6 \mathrm{~cm}$. A little bit smaller area in the comparison with the controlled variant were the plants grown by the cassette method with the size $2,5 \times 2,5 \mathrm{~cm}$. While comparing those methods it should be mentioned that the best index in leaf area was the plants grown by the cassette method. The only smaller than under the control area was the one with the cassette size of $2,5 \times 2,5 \mathrm{~cm}$.

The calculations of information on cross-correlation analysis prove that the head lettuce in seedling age exist direct strong dependence between the amount of leaves and by tier area. So, Alanis sort showed the lower result than under control 0,88 and while using the cassette method $-0,99-1,0$ and Stallion sort $0,80-1,0$. Confronting the amount of leaves and their average area we can also notice a strong dependence between these indexes $(r=0,90-1,0)$. The greatest cross-correlation connection at the probed sorts is noticed for the use of cassettes with the size of 
$4 \times 4 \mathrm{~cm}$ and $6 \times 6 \mathrm{~cm}$, and the smallest for the non-cassette method. Cross-correlation between the diameter and area of plants was 0,87-1,0 depending on the sort and method of seedlings planting. Strong connection between them was noticed when using the cassette method with the size of $4 \times 4 \mathrm{~cm}$ and $6 \times 6 \mathrm{~cm}(\mathrm{r}=1,0)$ and the smallest with the non-cassette method of growing.

One of the most important indexes of seedlings quality on any method of growing is the root system condition and correlation between root mass and mass of above-ground part. According to the researches results the lowest were the results with the non-cassette method of growing. So, at the moment of seedlings planting the greatest mass of the above-ground part and its better correlation was noticed with the plants grown at the cassettes with the size of $6 \times 6 \mathrm{~cm}$. Cassette seedlings with the diminishing stalk size was also diminished above-ground plant mass and root system. The cassette seedlings growing allowed almost completely saving the root system of plants that had a positive influence on their life and further development.

The final stage of the research is determination of the productivity of head lettuce. For the period of 2011-2012 there was noticed a certain difference in mass index and head diameter of lettuce, depending on their sort and method of seedlings planting.

During the researches there was noticed an advantage of the cassette method of growing over non-cassette method. Thus when using cassettes heads with the lowest mass were when growing at the cassettes with the stalk size of $2,5 \times 2,5 \mathrm{~cm}$ although this index was over control variant. The greatest head mass was when growing with cassette size of $4 \times 4 \mathrm{~cm}$. Lettuce heads differed also in diameter that was influence by method of seedlings growing and sort type of plants. It was proven that heads with greatest mass and diameter had plants with a crunchy leaves grown by the cassette method with the stalk size of $4 \times 4 \mathrm{~cm}$ (table 2).

During the period of researches it was proven that the method of seedlings growing has a great influence on the harvest formation and investigated that with the cassette method there were much more chances to get greater commodity harvest. 
Table 2

\section{Characteristics of head lettuce depending on the method of growing}

\begin{tabular}{|c|c|c|c|c|c|c|c|}
\hline \multirow{3}{*}{\multicolumn{2}{|c|}{$\begin{array}{l}\text { Method of growing and } \\
\text { cassette size }\end{array}$}} & \multicolumn{3}{|c|}{ Head mass, $\mathrm{g}$} & \multicolumn{3}{|c|}{ Head diameter ,cm } \\
\hline & & \multicolumn{2}{|c|}{ Years } & \multirow{2}{*}{$\begin{array}{l}\text { Average for } \\
2011-2012\end{array}$} & \multicolumn{2}{|c|}{ Years } & \multirow{2}{*}{$\begin{array}{l}\text { Average for } \\
2011-2012\end{array}$} \\
\hline & & 2011 & 2012 & & 2011 & 2012 & \\
\hline \multicolumn{8}{|c|}{ Alanis sort } \\
\hline \multicolumn{2}{|c|}{ Non-cassette - control } & 370,0 & 405,0 & 387,5 & 14,6 & 16,0 & 15,3 \\
\hline \multirow{3}{*}{ Cassette } & $2,5 \times 2,5 \mathrm{~cm}$ & 394,0 & 383,0 & 388,5 & 14,7 & 14,3 & 14,5 \\
\hline & $4 \times 4 \mathrm{~cm}$ & 452,0 & 473,0 & 462,5 & 17,0 & 17,5 & 17,3 \\
\hline & $6 \times 6 \mathrm{~cm}$ & 409,0 & 435,0 & 422,0 & 14,5 & 15,0 & 14,8 \\
\hline \multicolumn{2}{|c|}{$\begin{array}{c}\text { the least significant } \\
\text { difference }\end{array}$} & 23,5 & 25,6 & - & 0,6 & 0,9 & - \\
\hline \multicolumn{8}{|c|}{ Stallion sort } \\
\hline \multicolumn{2}{|c|}{ Non-cassette - control } & 612,6 & 610,0 & 611,3 & 22,3 & 22,0 & 22,2 \\
\hline \multirow{3}{*}{ Cassette } & $2,5 \times 2,5 \mathrm{~cm}$ & 617,0 & 650,0 & 633,5 & 22,0 & 22,6 & 22,3 \\
\hline & $4 \times 4 \mathrm{~cm}$ & 710,0 & 715,3 & 712,7 & 24,2 & 24,2 & 24,2 \\
\hline & $6 \times 6 \mathrm{~cm}$ & 664,0 & 673,0 & 668,5 & 25,0 & 25,2 & 25,1 \\
\hline \multicolumn{2}{|c|}{$\begin{array}{l}\text { the least significant } \\
\text { difference }\end{array}$} & 37,6 & 20,4 & - & 1,6 & 2,0 & - \\
\hline
\end{tabular}

Thus when growing with the usage of non-cassette method there was received $4,3 \mathrm{~kg} / \mathrm{m}^{2}$ of commodity lettuce heads of Alanis and $6,7 \mathrm{~kg} / \mathrm{m}^{2}$ of Stallion. With the usage of cassettes this index was $0,3-1,1 \mathrm{~kg} / \mathrm{m}^{2}$ higher. The higher harvest level was noticed with the usage of cassettes stalk size of $4 \times 4 \mathrm{~cm}$ and the lowest it was with the cassette stalk size $2,5 \times 2,5 \mathrm{~cm}$. So usage of the cassettes gave the possibility to get more production of Alanis on 7,0-18,6\%, Stallion - 4,5-16,4\% in accordance with the control (table 3).

There is a direct dependence between head diameter and its mass in the phase of technical ripeness according to the calculation of cross-correlation analysis. Crosscorrelation coefficient of Alanis sort is $0,88-0,99$ and Stallion sort is $0,99-1,0$ depending on the method of seedlings growing. It should be mentioned that those plants that were grown using the non-cassette method the cross-correlation connection is lower than plants grown from the cassette method. 
Table 3

\section{Head lettuce commodity productivity depending on the lettuce}

method of growing, $\mathrm{kg} / \mathrm{m}^{2}$

\begin{tabular}{|c|c|c|c|c|c|c|}
\hline \multirow{2}{*}{\multicolumn{2}{|c|}{$\begin{array}{l}\text { Method of growing and } \\
\text { cassette size }\end{array}$}} & \multicolumn{2}{|c|}{ Years } & \multirow{2}{*}{$\begin{array}{l}\text { Average for } \\
2011-2012\end{array}$} & \multicolumn{2}{|c|}{ Control rejection } \\
\hline & & 2011 & 2012 & & $\mathrm{~kg} / \mathrm{m}^{2}$ & $\%$ \\
\hline \multicolumn{7}{|c|}{ Alanis sort } \\
\hline \multicolumn{2}{|c|}{ Non-cassette - control } & 4,1 & 4,5 & 4,3 & 0 & 0 \\
\hline \multirow{3}{*}{ Cassette } & $2,5 \times 2,5 \mathrm{~cm}$ & 4,3 & 4,2 & 4,3 & 0 & 0 \\
\hline & $4 \times 4 \mathrm{~cm}$ & 5,0 & 5,2 & 5,1 & $+0,8$ & $+18,6$ \\
\hline & $6 \times 6 \mathrm{~cm}$ & 4,5 & 4,8 & 4,6 & $+0,3$ & $+7,0$ \\
\hline \multicolumn{2}{|c|}{ the least significant difference } & 0,2 & 0,4 & \multicolumn{3}{|c|}{-} \\
\hline \multicolumn{7}{|c|}{ Stallion sort } \\
\hline \multicolumn{2}{|c|}{ Non-cassette - control } & 6,7 & 6,7 & 6,7 & 0 & 0 \\
\hline \multirow{3}{*}{ Cassette } & $2,5 \times 2,5 \mathrm{~cm}$ & 6,8 & 7,2 & 7,0 & $+0,3$ & $+4,5$ \\
\hline & $4 \times 4 \mathrm{~cm}$ & 7,8 & 7,9 & 7,8 & $+1,1$ & $+16,4$ \\
\hline & $6 \times 6 \mathrm{~cm}$ & 7,3 & 7,4 & 7,4 & $+0,7$ & $+10,4$ \\
\hline \multicolumn{2}{|c|}{ the least significant difference } & 0,3 & 0,5 & \multicolumn{3}{|c|}{-} \\
\hline
\end{tabular}

Conclusions. Consequently with the usage of cassettes the leaves area of the head lettuce plants is increased with the increase of stalk size. At the moment seedling planting the greatest mass of the above-ground part had the plants grown in the cassettes with the stalk size of $6 \times 6 \mathrm{~cm}$. At the cassette seedlings mass of aboveground part of plants and root age diminishes with the diminishing of stalk size. Heads with greater mass and diameter appear at plants grown with the cassette method with a stalk size of $4 \times 4 \mathrm{~cm}$. Researches proved that in order to receive a high head lettuce production there should be used the cassette, method of growing with the size of $4 \times 4 \mathrm{~cm}$.

\section{The list of used literature resources}

1. Сыч 3. Д. Овощ будущего - салат / 3. Д. Сыч, И. М. Бобось // Овощеводство. - 2011. - № 5. - С. 4-5.

2. Салат [Електронний ресурс]. - Режим доступу до статті : http://kvitkar.ru/posadochnii_material/2.html 
3. Гладков Д. С. Селекция салата (Lactuca sativa) для проточной культуры / Д.С. Гладков. [Електронний ресурс]. - Режим доступу до статті : http://www.ponics.ru/2009/10/lactuca_sativa/\#more-2929

4. Салат посевной [Електронний ресурс]. - Режим доступу до статті : http://www.sort-semena.ru/vegetech/salat.html

5. Бондаренко Г.Л. Методичні рекомендації 3 касетної технології виробництва овочевих культур / Г.Л. Бондаренко. - К. : Вища школа, 1992. C. 22 .

6. Методика дослідної справи в овочівництві і баштанництві / За ред. Г. Л. Бондаренко, К. І. Яковенко. - Харків: Основа, 2001. - 369 с.

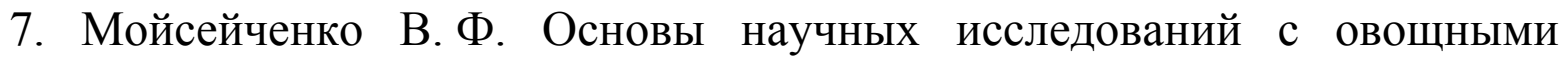
культурами в защищенном груне / В. Ф. Мойсейченко. - К.: УСХА, 1990. - 76 с.

8. Грицаєнко 3. М. Методи біологічних та агрохімічних досліджень рослин і грунтів / 3. М. Грицаєнко, А. О. Грицаєнко, В. П. Карпенко. - К.: ЗАТ «НІЧЛАВА», 2003. - 316 с.

\section{Анотація}

\section{Кецкало В.В.}

\section{Продуктивність салату головчастого у весняній теплиці}

Наведено результати дослідження ефективності вирощування салату головчастого сортів Аланіс та Сталліон розсадним способом у закритому трунті. Встановлено вплив способу вирощування та площі живлення рослин у розсадний період на їх ріст, розвиток $і$ біометричні показники. Визначено рівень урожайності, продуктивність та товарність одержаної продукиії.

Ключові слова: салат головчастий, розсада, касета, сорт Аланіс, сорт Сталліон, урожайність

\section{Аннотация}

Кецкало В.В.

Продуктивность салата кочанного в весенней теплице 
Приведень результаты исследований эффективности выращчивания салата кочанного сортов Аланис и Сталлион рассадным способом в закрытом грунте. Установлено влияние способа выращуивания и площуади питания растений в рассадньй период на их рост, развитие и биометрические показатели. Определен уровень урожайности, производительность $u$ товарность полученной продукции.

Ключевые слова: салат кочанный, рассада, кассета, сорт Аланис, сорт Сталлион, урожайность

Отримано редакцією-08.10.2013 р. 